\title{
EDITORIAL
}

\section{DOENÇA DA ARRANHADURA DO GATO E AIDS}

Rochalimaea henselae é uma nova espécie de microorganismo ora incluída na ordem Rickettsiales, a que vem sendo atribuída a etiologia da maioria dos casos da doença da arranhadura do gato (cat scratch disease - CSD). Até recentemente, o diagnóstico desta afeç̧ão, como referido por Margileth e Hayden ${ }^{6}$, baseava-se em dados clínicos, caracteristicamente, linfadenite regional unilateral satélite à pápula no local de inoculação, não raro relacionada com arranhadura ou contacto com gato, febre de longa duração, eventualmente, graves manifestações de encefalite ou neurorretinite, na exclusão de outras causas como micobactérias; na presença de múltiplos microabcessos ou granulomas ao exame histológico do gânglio, e na positividade de teste intradérmico com aspirado de gânglio de casos típicos da doença. A observação de microorganismos em gânglios e nas lesões, pela coloração argêntea de Warthin-Starry, veio sugerir uma etiologia bacteriana ${ }^{14}$. Bacilos pleomórficos muito semelhantes, também coráveis pela prata, são encontrados em aglomerados nas lesões vasculares, cutâneas, ósseas, viscerais ou disseminadas, da angiomatose bacilar e da peliose hepática ou esplênica, doença infecciosa que ocorre principalmente na AIDS, em pacientes imunodeficientes e mesmo em individuos imunocompetentes. Uma etiologia comum à CSD foi-lhe sugerida em 1988 por LeBoit e cols ${ }^{5}$.

Estes microorganismos foram inicialmente reconhecidos como pertencentes ao gênero Rochalimaea, pela identificação de segmentos característicos de DNA correspondentes ao segmento 16S de RNA ribosomal de eubacteriáceas, clonados a partir desses tecidos, com "primers" de oligonucleotídios comuns às eubacteriáceas, e amplificados pela reação eñ cadeia da polimerase. Estes segmentos mostraram estrutura muito próxima àquela característica da Rochalimaea quintana, agente da "febre das trincheiras" 8 . Posteriormente isolados por cultura ${ }^{3} 12$, a $R$. quintana principalmente de pacientes infectados pelo HIV-1, uma nova espécie, a $R$. henselae, foi identificada $\mathrm{e}$ descrita $^{8}$. Bacilo pleomórfico, gram-negativo, de

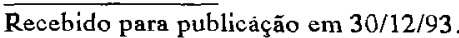

\section{CAT SCRATCH DISEASE AND AIDS}

Rochalimaea henselae is a new recognized species of microorganisms presently included in the order Rickettsiales, that seems to be the cause of most cases of cat-scratch disease (CSD). As summarized by Margileth and Hayden ${ }^{6}$ until recently CSD diagnosis was based on clinical data, characteristically unilateral regional lymphadenitis related to a papule at the site of inoculation, frequently with a history of scratch or contact with a cat, long standing fever, eventually more severe manifestations, as meningoencephalitis, neuroretinitis; histologically, on the presence of multiple microabcesses or granulomas in lymphnodes; also, on the exclusion of other recognized causes, as mycobacteria, and on a skin-test positive response to aspirates from lymph-nodes of known cases of the disease. Detection of pleomorphic bacilli by the Warthin-Starry silver staining in biopsies of lymph-nodes or lesions suggested a bacterial etiology for the disease ${ }^{14}$. Clusters of very similar silver-stained microorganisms are also found in the characteristic cutaneous, osseous or visceral vascular lesions of bacillary angiomatosis and peliosis hepatis, an infectious disease which occurs mainly in AIDS and other immunocompromized patients and eventually in immunocompetent individuals. A common etiology with CSD was suggested by LeBoit e cols in $1988^{5}$. These microorganisms were first reconized as belonging to the genus Rochalimaea, through the identification in infected tissues of characteristic DNA segments, with the help of oligonucleotide primers complementary to the $16 \mathrm{~S}$ ribosomal RNA genes of eubacteriacea. These were cloned, amplified by PCR and the DNA sequenced ${ }^{8}$. Later on, these bacilli could be isolated by culture ${ }^{3412}$ and, besides Rochalimaea quintana, known as the agent of the "trench fever", then detected mainly in immunocompromized patients, a new species, Rochalimaea henselae, was identified and described $^{8}$. A fastidious, slow-growing, gramnegative pleomorphic bacillus, $R$. henselae could 
crescimento lento, a $R$. henselae foi isolada de casos humanos de CSD e de gatos ${ }^{29}$ por hemocultura e cultivo de material de gânglio, bem como de pacientes com angiomatose bacilar ou com febre $e$ bacteremia ${ }^{3471215}$. Tal isolamento pode ser obtido semeando-se homogeneizados de tecidos ou sangue lisado, diretamente em placas recém preparadas de ágar-sangue ou de ágar-chocolate, incubadas a 35$36^{\circ} \mathrm{C}$ por 2 a 4 semanas em atmosfera de $\mathrm{CO}_{2}$ a $5 \%$.

Testes de imunofluorescência indireta com $R$. henselae e com $R$. quintana, de preferência cocultivadas com células, tais como a linhagem VERO, têm revelado altos títulos de anticorpos específicos para $R$. henselae (de 1:64 a mais de 1:30.000) em cerca de $90 \%$ dos casos de CSD investigados ${ }^{10} \mathrm{e}$ possibilitado a realização de estudos soroepidemiológicos que vêm revelar um amplo espectro de manifestações clínicas para a $\mathrm{CSD}^{16}$. Estes anticorpos são também freqüentes nos gatos domésticos, encontrados por Olson e Regnery em cerca de $30 \%$ daqueles testados em Atlanta, GA, USA (comunicação pessoal), o que tem sido por nós confirmado na cidade de São Paulo (a ser publicado). Anticorpos para uma ou outra espécie têm sido encontrados também em pacientes com infecções por Rochalimaea, como a angiomatose bacilar ou febrecom bacteremia. Técnicas de imunocitoquímica têm sidoeficientemente utilizadas para a identificação de $R$. henselae e de $R$. quintana em tecidos?.

Anteriormente, a etiologia da CSD havia sido atribuída a uma bactéria recentemente identificada, a Afipia felis ${ }^{1}$ mas dados atuais, inclusive sorológicos, não o confirmam, fazendo-se necessárias maiores investigações para esclarecimento.

Excelente revisão clínica, microbiológica e diagnóstica de infecções por Rochalimaea em indivíduos infectados pelo HIV - 1 , com boailustração fotográfica das lesões da angiomatose bacilar, inclusive de aspectos histológicos, foi recentemente publicada por Koehler e Tappero ${ }^{4}$, que também discutem sua epidemiologia, prevenção e tratamento.

Embora mal conhecidos, os mecanismos de transmissão entre gatos e destes para o homem, eventualmente, talvez, através de pulgas, a elevada prevalência e aparente longa duração da infecção por $R$. henselae em gatos ${ }^{9}$, aliada ao contacto freqüente com esses animais, fazem prever que a infecção humana deva ser relativamente comum, be isolated from human cases of CSD and from cats by lymph-node and blood cultures ${ }^{2}{ }^{9}$, as well as from patients with bacillary angiomatosis or fever and bacteremia ${ }^{3471215}$. Isolation can be obtained by direct seeding of tissue homogenates or lysed blood on fresh blood-agar or chocolate agar plates, usually after 2 to 4 weeks incubation in $5 \% \mathrm{CO}_{2}$, at 35 $36^{\circ} \mathrm{C}$.

A fluorescent antibody test with either species, preferably co-cultivated with mamal cell lines as VERO, has indicated high titer antibodies for $R$. henselae (1:64 to higher than 1:30,000) in about $90 \%$ of the CSD cases investigated ${ }^{10}$ and has permitted seroepidemiological studies ${ }^{16}$ which indicate the infection may assume broad spectra of clinical manifestations. These antibodies are also frequent in domestic cats, observed by Olson and Regnery in about $30 \%$ of cats in Atlanta, GA, USA (personal communication), and as we have been finding in São Paulo (to be published). Antibodies to one species or other have also been found in patients with Rochalimaea infections, as angiomatosis or fever and bacteremia. Immunocytochemical techniques have been successfully employed for the identification of $R$. henselae and $R$. quintana in tissues ${ }^{7}$.

Cat scratch disease has been previously associated with Afipia felis ${ }^{1}$, a recently identified microorganism that was even called the CSD bacillus, but present data, including serologic, do not confirm such etiology at least in most cases of the disease and more investigation is certainly necessary to clear up its pathogenicity.

An extensive revision of Rochalimaea infections in AIDS patients has been recently published by Koehler and Tappero ${ }^{4}$, with macroscopic and histologic illustrations of bacillary angiomatosis lesions and a thorough discussion on the diagnosis, clinical, bacteriologic and serologic, as well as on epidemiology and treatment.

Mechanisms of transmission of the infection among cats and human beings are not well known and fleas might contribute to it. Large population of cats in close contact with humans, and the high prevalence and long duration of cat infection", 
Editorial. Camargo ME. Doença da arranhadura do gato e AIDS. Revista da Sociedade Brasileira de Medicina Tropical 27:65-67, abr-jun, 1994.

inclusive como infecção oportunista. Realmente, depois do desenvolvimento das técnicas atuais, especialmente dos testes sorológicos, o número de casos diagnosticados vem aumentando sensivelmente, bem como sendo evidenciado o polimorfismo de suas manifestações clínicas ${ }^{16}$. make it probable human infection to be frequent. Really, with the development of present techniques of diagnosis, mainly serology, a rising number of cases is being observed, as well as the polymorphism of their clinical manifestations ${ }^{16}$.

\section{REFERÊNCIAS BIBLIOGRÁFICAS}

1. Brenner DJ, Hollis DG, Moss CW, English CK, Hall GS, Vincent J, Radosevic J. Proposal of Afipia gen. nov., with Afipiafelis sp. nov. (Formerly the cat scratch disease bacillus), Afipia clevelandensis sp. nov. (Formerly the Cleveland clinic foundation strain), Afipia broomeae sp. nov. and three unnamed genospecies. Journal of Clinical Microbiology 29:2450-2460, 1991.

2. Dolan MJ, Wong MT, Regnery RL, Jorgensen JH, Garcia M, Peters J, Drehner D. Syndrome of Rochalimaea henselae adenititis suggesting cat scratch disease. Annals of Internal Medicine 118:331336, 1993.

3. Koehler JE, Quinn FD, Berger TG, LeBoit PE, Tappero JW. Isolation of Rochalimaea species from cutaneous and osseous lesions of bacillary angiomatosis. The New England Joumal of Medicine 23:1625-1631, 1992.

4. Koehler JE, Tappero JW. Bacillary angiomatosis and bacillary peliosis in patients infected with human immunodeficincy virus. Clinical Infectious Diseases 17:612-624, 1993.

5. LeBoit PE, Berger TG, Egbert BM. Epithelioid haemangioma-like vascular proliferation in AIDS: manifestation of cat-scratch disease bacillus infection. Lancet 1:960-963, 1988.

6. Margileth AM, Hayden GF. Cat scracth disease. From feline affection to human infection. The New England Journal of Medicine 329:53-54, 1993.

7. Reed JA, Brigati DJ, Flynn SD, McNutt NS, Min KW, Welsh DF, Slater LN. Immunocytochemical identification of Rochalimaea henselae in bacillary (epithelioid) angiomatosis, parenchimal bacillary peliosis, and persistent fever with bacteremia. The American Journal of Surgical Pathology 16:650657, 1992.

8. Regnery RL, Anderson BE, Clarridge III JE, Rodrigues-Barrada MC, Jones DC, Carr JH. Characterization of a novel Rochalimaea species, $R$. henselae sp. nov., isolalet from blood of a febrile, human immunodeficiency virus-positive patient. Journal of Clinical Microbiology 30:265-274, 1992.

9. Regnery RL, Martin M, Olson J. Naturally occurring Rochalimaea henselae infection in domestic cat. Lancet 340:557, 1992.

10. Regnery RL, OLson JG, Perkins BA, Bibb W. Serological response to Rochalimaea henselae antigen in suspected cat-scratch disease. Lancet 339:1443-1445, 1992.

11. Slater LN, Coody DW, Woolridge LK, Welch DF. Murineantibody responses distinguish Rochalimaea henselae from Rochalimaea quintana. Journal of Clinical Microbiology 30:1722-1727, 1992.

12. Slater LN, Welch DW, Hensel D, Coody DW. A newly recognized Gram-negative pathogen as a cause of fever and bacteremia. The New England Journal of Medicine 23:1587-1593, 1990.

13. Tappero J, Regnery R, Koehler J, Olson J. Detection of serologic response to Rochalimaea henselae in patients with bacillary angiomatosis (BA) by immunofluorescent antibody (IFA) testing (abstract 674) $I n$ : Program and abstracts of the $32^{\text {nd }}$ intensive Conference on Antimicrobial Agents Chemotherapy. Washington DC. American Society for Microbiology, 1992.

14. Wear DJ, Margileth AM, Handfield TL, Fisher GW, Schlagel CJ, King FM. Cat scratch disease: a bacterial infection? Science 221:1403-1405, 1983.

15. Welch DF, Pickett DA, Slater LN, Steigerwalt AG, Brenner DJ. Rochalimaea henselae sp. nov., a cause of septicemia, bacillary angiomatosis, and parenchymal bacillary peliosis. Journal of Clinical Microbiology 30:275-280, 1992.

16. Zangwill KM, Hamilton DH, Perkins BA, Regnery RL, Plifaytis BD, Hadler JL, Cartter ML, Wenger JD. Cat scratch disease in Connecticut. Epidemiology, risk factors, and evaluation of a new diagnostic test. New England Journal of Medicine 329:6-13, 1993. 